\title{
Transformation of Phosphorite Into Nano-Phosphate in Alkaline Medium
}

\author{
Nimbona Guillaume ${ }^{\mathrm{a}, *}$, Yaya Mahamat Idriss ${ }^{\mathrm{a}}$, Abdellah Ech-Chahad ${ }^{\text {a }}$ \\ aUniversity Hassan I, \\ Laboratory of Applied Chemistry and Environment, \\ Faculty of Sciences and Technology, BP 577 Settat (Morocco)
}

\begin{abstract}
In this work, we have applied the alkaline extraction technique to natural phosphate in order to manufacture a non-stoichiometric hydroxyapatitic nano-phosphate. For this purpose, we have used an alkaline salt as digesting agent. The obtained residue of digestion has been subjected on the gelation process in solution. The characterization of the obtained apatite with XRD, FTIR and SEM techniques showed that the use of this method has proved that it is possible to keep the crystallographic and chemical structure of any natural phosphate as opposed to the usual process of acid attack phosphates which leads to total or partial dissolution of apatite. The obtained apatite has a hydroxyapatitic structure and nano-particle size. The substitution of fluorine $\left(\mathrm{F}^{-}\right)$by ions $\left(\mathrm{OH}^{-}\right)$during the digestion process has been facilitated by the presence of reactive silica in our rock phosphate sample.
\end{abstract}

Keywords: Phosphate rock, Granulometry, Alkaline extraction, Hydroxyapatite, Sieving

\section{INTRODUCTION}

It is a known fact that the economic potential of a crude phosphate is linked to its high content of $\mathrm{P}_{2} \mathrm{O}_{5}$ but its temporal and environmental sustainability is very important because it is a non-renewable resource [1-2-3]. A suitable process for a potentially sustainable treatment would be such that, while saving the raw material by dividing it on a nanoscale, should makes it possible to manufacture a phosphate which would be not only rich in $\mathrm{P}_{2} \mathrm{O}_{5}$ but should keep an apatitic structure as close to its natural shape as possible. In fact, natural phosphates are generally associated with several mineralogical species (limestone, quartz, periclase, fluorite, clays, silica, etc.), but the essential component is apatite [4-5]. The apatites have as general formula $\mathrm{M}_{10}\left(\mathrm{MO}_{4}\right)_{6} \mathrm{X}_{2}$ where $\mathrm{M}$ represents a divalent cation $\left(\mathrm{Ca}^{2+}, \mathrm{Mg}^{2+}, \mathrm{Sr}^{2+}\right.$, etc. $), \mathrm{MO}_{4}$ a divalent, trivalent or tetravalent oxo-anion $\left[\left(\mathrm{CO}_{3}\right)^{2-},\left(\mathrm{PO}_{4}\right)^{3-},\left(\mathrm{SiO}_{4}\right)^{4-}\right.$, etc.] and $\mathrm{X}$ a monovalent anion $\left(\mathrm{F}^{-}, \mathrm{OH}^{-}\right.$, etc.) [6-7-8]. Moroccan apatite can be considered as a biological apatite because of its content of organic carbonate as opposed to pure fluorapatite [9-10-11]. It should be noted that apatites have a relatively "complex" structure, which favors numerous anionic and cationic substitutions on the three ion exchange and binding sites $\left(\mathrm{M}, \mathrm{MO}_{4}\right.$ and $\left.\mathrm{X}\right)$ [12]. These ionic substitutions make it possible to understand why natural apatite ores can contain many impurities in variable quantities and which are difficult to eliminate by separating them with the apatite crystals which are so small that in one dimension they have only a thickness of about ten atomic layers [13].

This is why the quality of the commercial phosphate products is influenced by the presence of these impurities such as heavy metals $(\mathrm{Cd}, \mathrm{Sr}, \mathrm{Zn}, \mathrm{Mn}, \mathrm{Cu}, \mathrm{Pb}, \mathrm{Ni}, \mathrm{U}$, etc...). The elimination of these impurities in phosphate ores is therefore of great importance from both an economic and an environmental point of view. The complexity of the mineralogical and chemical composition of natural phosphate has a great influence on the processes of their valorization [14]. Apatite ores are the main source of phosphate fertilizers and are used to prepare phosphoric acid and other various phosphate derivatives. However, these fertilizers are rarely produced and used as an apatite source because of their low solubility [15-16].

Acidic dissolution is a usual technique which is used for the manufacturing of fertilizers, but it is associated with numerous problems related to the denaturation of the apatitic structure due to the total loss of calcium and partial loss of phosphorus in the form of phosphogypsum $\left(\mathrm{CaSO}_{4} \cdot 2 \mathrm{H}_{2} \mathrm{O}+\mathrm{Ca}\left(\mathrm{H}_{2} \mathrm{PO}_{4}\right)_{2} \cdot 2 \mathrm{H}_{2} \mathrm{O}\right)$. Moreover, the use of acids is a potential hazard to the health and to environment. Further, acidic dissolution also adds incomplete digestion of certain refractory compounds such as rare earths if they exist in the ore, and will end up us impurities in the finished products [17].

The purpose of this study is to experiment the alkaline extraction method in presence of an alkaline salt as digesting agent for the transformation of natural phosphate into nano-apatite having a similar structure to hydroxyapatite.

\section{EXPERIMENTAL}

A. Enrichment of phosphorite into apatite by mechanical sieving

It should be noted that our raw phosphate sample was collected from the Gantour region of Morocco. First of all, or particles of size above $1 \mathrm{~mm}$ were removed from the starting phosphate ore. Then, mechanical sieving was carried out on two sieves with mesh openings measuring 710 and $180 \mu \mathrm{m}$ respectively. This operation makes it possible to enrich the ore in apatite by eliminating particles of granulometries under $180 \mu \mathrm{m}$ which are rich in silica, limestone, clay and fractions greater than $710 \mu \mathrm{m}$ which are rich in sterile stones to meet the commercial requirements that a quality fertilizer must have at least $70 \%$ BPL (Bone Phosphate of Lime) content. 


\section{B. Alkaline extraction of apatitic phosphate}

The purpose of the alkaline extraction method is to separate apatitic phosphate from other minerals, impurities and other non-valuable or less interesting materials surrounding apatite in its natural deposit called "gangue". The use of the alkaline extraction in presence of an alkaline salt was motivated by the fact that it is a method leading to nonstoichiometric apatites, which are generally more soluble than stoichiometric apatites. For this purpose, several alkaline digesting agent can be used and facilitate extraction, but our study focused on sodium carbonate because it is an environment friendly reagent. Digesting agents other than carbonates are generally environmental harmful. Another advantage of sodium carbonate is its high dissolving capacity of oxides, especially quartz [18]. We considered that the two sieves 180 and $710 \mu \mathrm{m}$ constituted a single granulometric class. The procedure consisted of taking the oversize from this granulomeyric class, and then subject it to an alkaline extraction in presence of sodium carbonate as digesting agent. The obtained residue was washed and dried at $80^{\circ} \mathrm{C}$ for 12 hours before undergoing further analyzes.

\section{CHARACTERIZATION METHODS.}

To identify the mineralogical phases, the residues obtained by sieving and alkaline extraction were subjected to X-ray diffraction analysis respectively. The used diffractometer is type BRUKER in reflection mode which is equipped with a LYNXEYE detector and a tube in copper with a wavelength of $\lambda=1.54 \ddot{A}$. The data were analyzed in the $2 \Theta$ range from $10^{\circ}$ to $80^{\circ}$ with a scanning step of $2^{\circ}$ per minute. The morphology and size of the phosphate particles obtained were determined by the complementary use of scanning electron microscopy (SEM) and the LaueScherer relationship [19]:

$$
S_{c}=\frac{0.9 * \lambda}{F W H M * \cos \theta}
$$

Where $S_{c}$ is the average crystallite size (in $\mathrm{nm}$ ); $\lambda$ is the wavelength of X-ray radiation; FWHM is the full width at half maximum for the diffraction peak under consideration (rad); and $\theta$ (degree) is the diffraction angle of the investigated peak. Functional groups of apatite obtained by alkaline extraction were characterized by Fourier Transform Infrared Spectroscopy (FTIR).

\section{RESULTS AND DISCUSSION}

The X-ray diffraction analysis spectra of the crude phosphate sieved in the range [180-710 $\mu \mathrm{m}$ [ revealed four detectable major phases. These phases correspond respectively to apatite, fluorite, quartz and dolomite. These results allowed us to focus on the identification of the phases constituting the crude apatite in the range [180-710 $\mu \mathrm{m}[$. At first sight, these results shown that Gantour phosphate sieved between $180 \mu \mathrm{m}$ and $710 \mu \mathrm{m}$ is a fluorapatite $\mathrm{Ca}_{10}\left(\mathrm{PO}_{4}\right)_{6} \mathrm{~F}_{2}$ (as shown in Fig. 1) if we compare it with PDF sheet $\mathrm{N}^{\circ} 15-0876$.

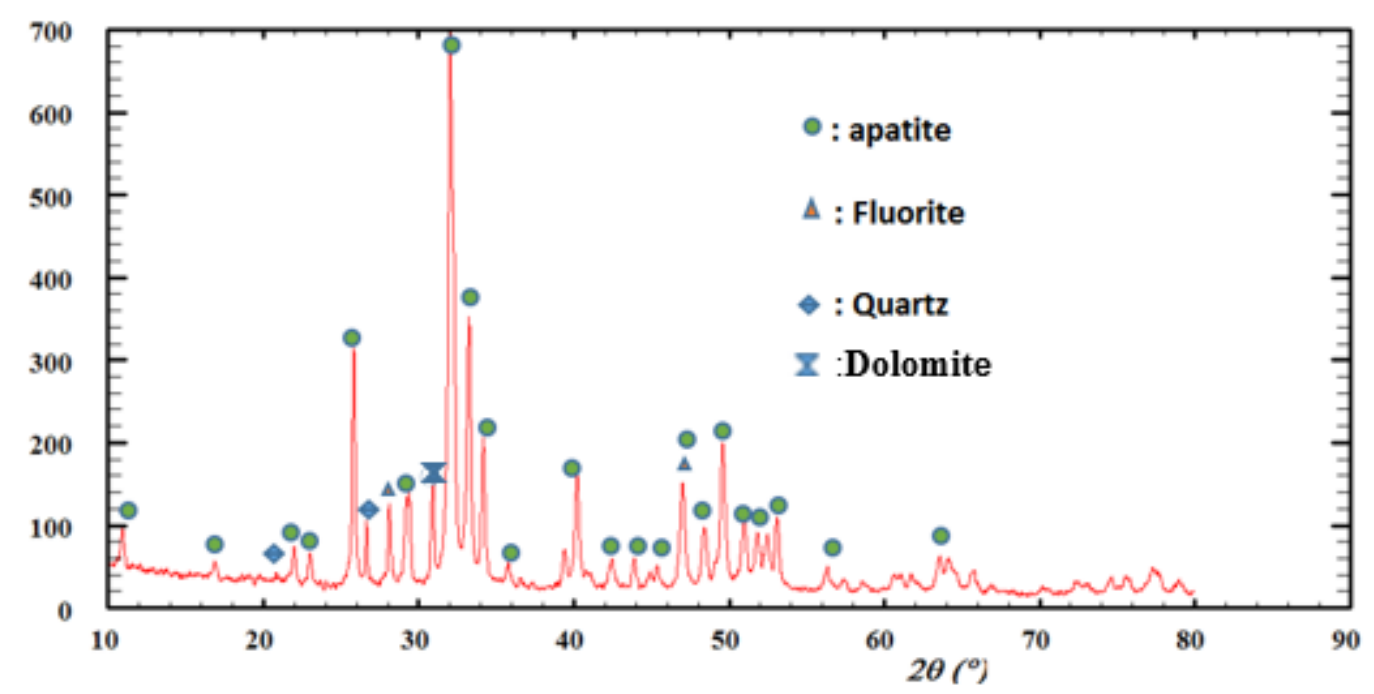

Fig. 1: XRD spectrum of crude phosphate sieved in the range [180-710 $\mu \mathrm{m}[$

To judge the effectiveness of our alkaline extraction process in presence of a digesting agent, the digestion product (snow-white powder) was subjected to X-ray diffraction analysis in order to identify the nature of the remaining phases and to calculate the particle size. The spectrum of Fig. 2 shows the disappearance of peaks corresponding to the quartz and Dolomite, which had been detected in the raw phosphate sample (Fig. 1). The keeping of all the spectral lines corresponding to the apatitic phase proves that the phosphated fraction is single-phase. Reactive silica which is amorphous silica cannot be detected by using X-Ray Diffractometry (XRD). However, this silica contribute to remove fluorine during fusion process [20]: 
$6 \mathrm{Ca}_{5}\left(\mathrm{PO}_{4}\right)_{3} \mathrm{~F}+4 \mathrm{H}_{2} \mathrm{O}+\mathrm{SiO}_{2} \leftrightarrow 6 \mathrm{Ca}_{5}\left(\mathrm{PO}_{4}\right)_{3}(\mathrm{OH})+2 \mathrm{HF}+\mathrm{SiF}_{4}$

(2)

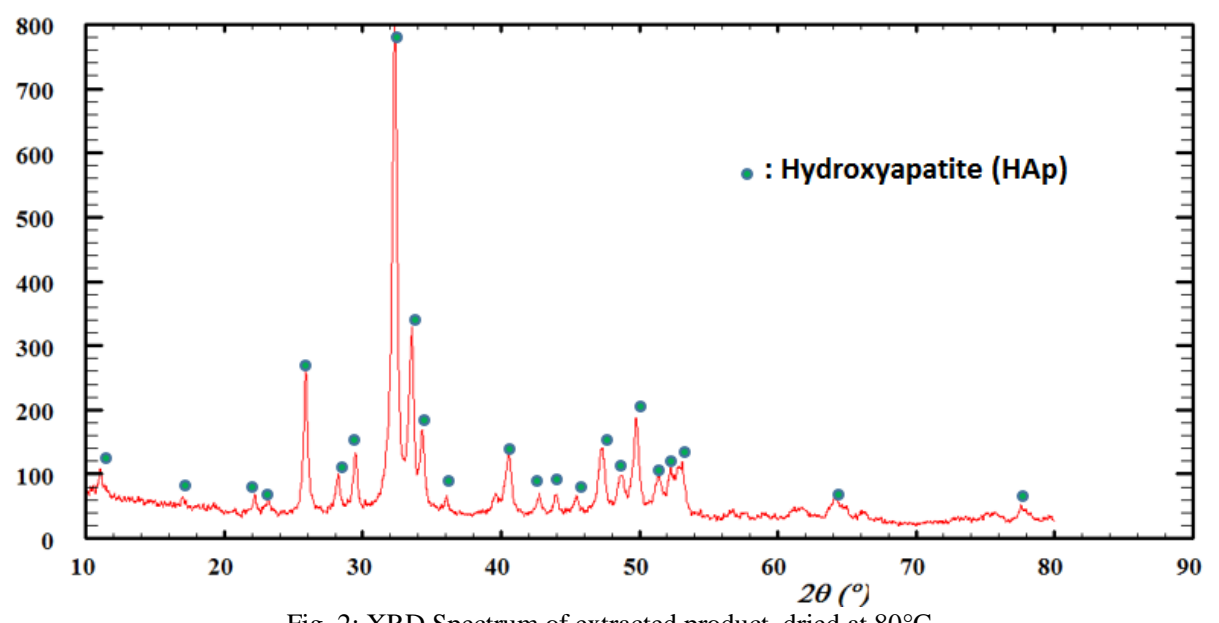

Fig. 2: XRD Spectrum of extracted product, dried at $80^{\circ} \mathrm{C}$

The disappearance of the peaks relative to quartz, dolomite and fluorite proves that sodium carbonate is indeed specific to the removal for even the most refractory components [21-22-23]. As for fluorine contained in the apatite structure, the XRD spectrum (Fig. 2) shows at first sight that the fluorapatite (FAp) was transformed into hydroxyapatite (HAp) compared to the pdf sheet $\mathrm{N}^{\circ} 09$ 0432. However, a chemical microanalysis as well as an infrared spectroscopy analysis are necessary in order to be able to confirm the XRD analysis result of Fig.2.

Concerning the calculation of the particle size of the synthesized HAp nano-powders, XRD analysis is a quantification method by which can be performed. It is known that the full width at half maximum (FWHM) of a diffraction peak is due to the thickness effect " $S_{c}$ " of the crystallites [24] and is measured for clay and similar materials such as phosphates and double hydroxides on 00L [25].

The particle size determined by the relationship (1) of Laue-Scherer has given a value of $27.5 \mathrm{~nm}$; which proves that the obtained apatite had a nanometric size. The obtained apatite was also calcined at $800^{\circ} \mathrm{c}$ for 4 hours. The aim of this calcination was to convert the apatite in hydroxyapatite nanopowders with high crystallinity. The calcined product was then analyzed by X-ray diffraction and the results were presented below:

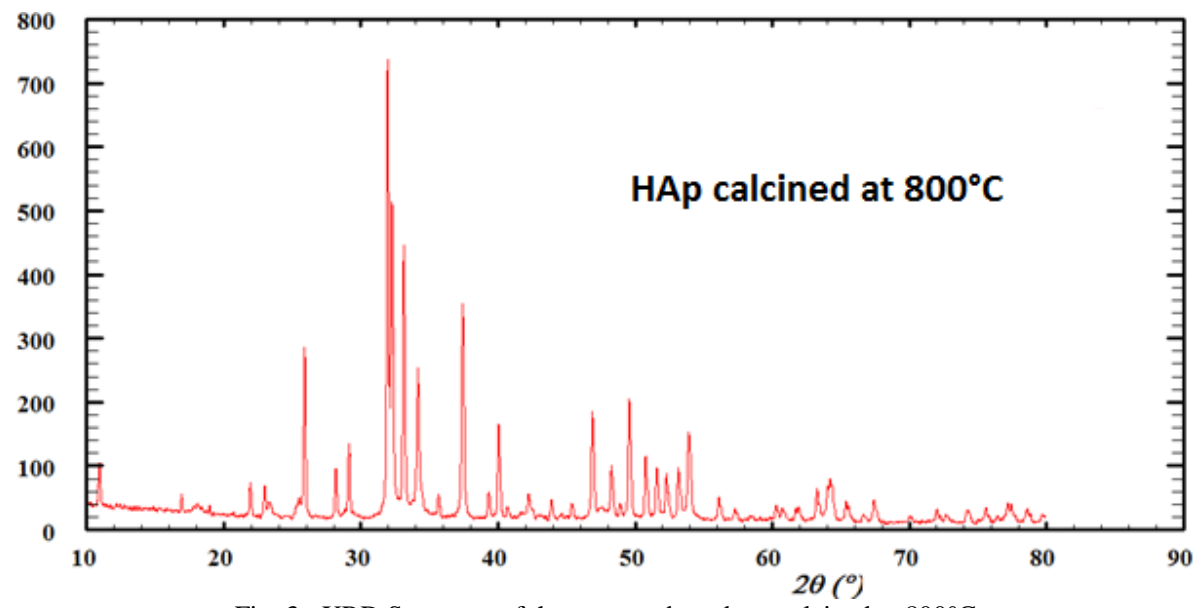

Fig. 3: XRD Spectrum of the extracted product, calcined at $800^{\circ} \mathrm{C}$

The XRD spectrum of the calcined HAp shows very fine peaks indicating the decrease of porosity as well as an increase of the crystallinity. The calcination has led to the closing of many small pores of Hap dried at $80^{\circ} \mathrm{C}$. We can conclude that the ceramization at high temperature of HAp should be constituted a potential route for the manufacturing of implants for bone substitution in the medical field.
To identify the functional groups of the obtained apatite, we used an Infrared Spectrometer "SCO-TECH" type whose scanning spectral range is from $4000 \mathrm{~cm}^{-1}$ to 400 $\mathrm{cm}^{-1}$ with $2 \mathrm{~cm}^{-1}$ a spectral resolution. The analysis was carried out on the dried and calcined apatite because the calcination allows to visualize well the main functions, which characterize the obtained apatite. The results of analysis were presented in Fig. 4 below: 


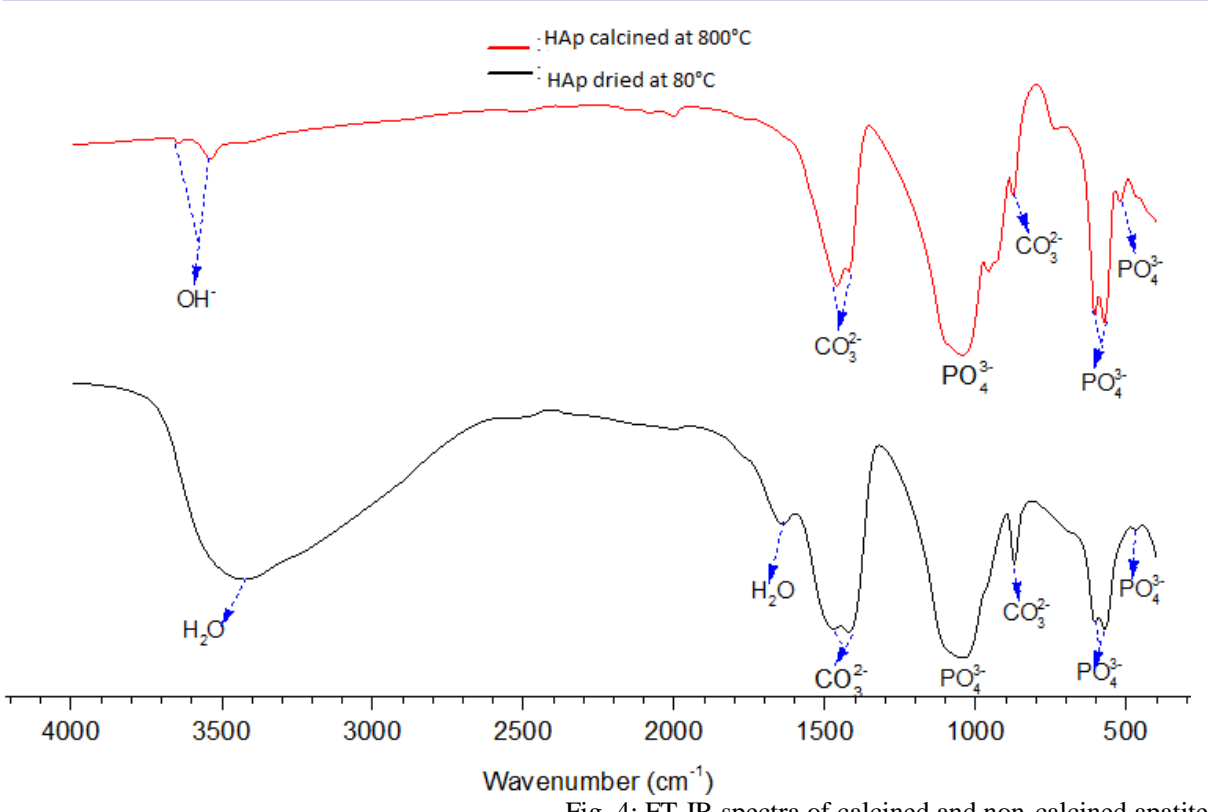

The vibration bands observed respectively at $1640 \mathrm{~cm}^{-1}$ and $3425 \mathrm{~cm}^{-1}$ for apatite dried at $80^{\circ} \mathrm{C}$ are attributable to the adsorbed molecules of $\mathrm{H} 2 \mathrm{O}$ [26-27]. The very broad band corresponding to the absorption of water, observed at 3425 $\mathrm{cm}^{-1}$, could indicate the existence of a very high absorption area. After calcination, we notice the appearance of the peaks at $3700 \mathrm{~cm}^{-1}$ corresponding to the groups $(\mathrm{OH})^{-}$. This shows that the alkaline extraction technique has allowed us to transform the fluorapatite form of natural phosphate into hydroxyapatite. The vibration bands observed at 1040, 605, 572 and $467 \mathrm{~cm}^{-1}$ are attributable to the phosphate groups $\left(\mathrm{PO}_{4}\right)^{3-}$ while the bands appearing at 1458 and $1427 \mathrm{~cm}^{-1}$ correspond to the carbonates $\left(\mathrm{CO}_{3}\right)^{2-}$ which are located in the site B of the apatitic structure [28] but the peak at 875 $\mathrm{cm}^{-1}$ corresponds to dolomitic carbonate.

Finally, the study of morphology of the obtained powders were made by SEM. The results were presented in the Fig. 5 below:

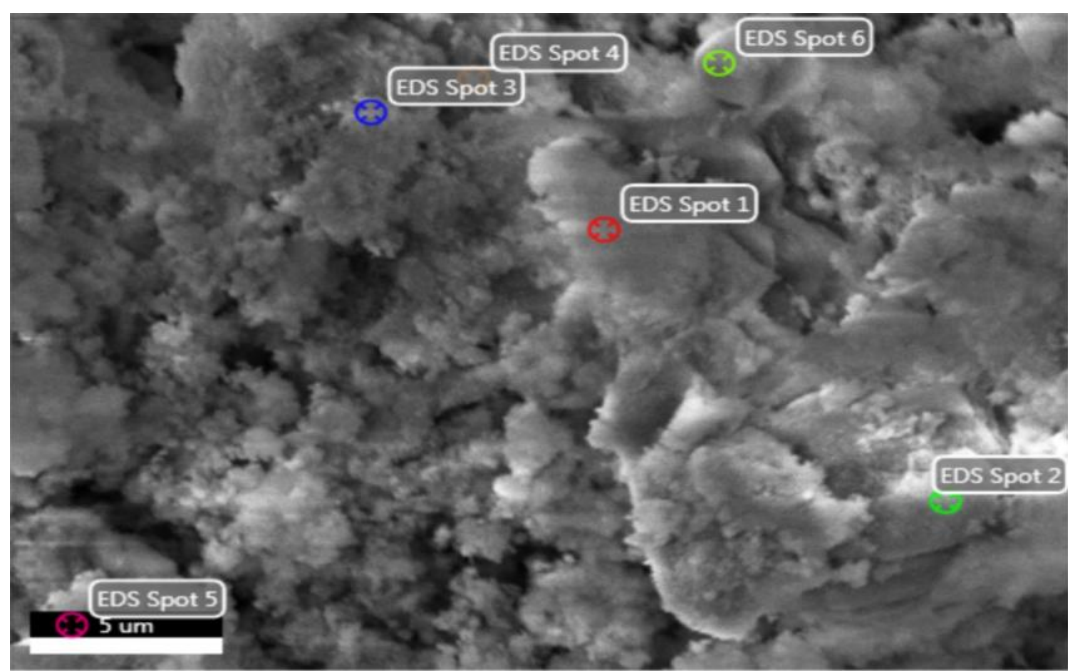

Fig. 5: SEM image of Hydroxyapatite (Hap) from alkaline extraction with sodium carbonate

The results shown that the alkaline extraction product from the oversizes obtained in the range [180-710 $\mu \mathrm{m}$ [ rich in phosphate gave clumps of poorly crystallized fractal-like particles, thus developing a high porosity.

\section{CONCLUSION}

Since phosphates are weakly soluble to be applied alone as a fertilizer without any addition, we believe that this type of fertilizer can only be directly assimilated by plants if they are produced at a nanoscale level. The process of alkaline extraction that we have applied to Moroccan phosphate, preceded by a prior mechanical sieving carried out between two sieves of 180 and $710 \mu \mathrm{m}$, has allowed us to manufacture a phosphate having a nanometric size. However, the potential solubility of Gantour phosphate can be favoured by the incorporation of carbonate and silicate ions into the apatitic structure with the use of this new process. In addition, it is possible to avoid the major shortcomings encountered in the traditional technique based on acidic attack of phosphates due to the significant loss of phosphorous material in phosphogypsum form: 
$\mathrm{CaSO}_{4} \cdot 2 \mathrm{H}_{2} \mathrm{O}+\mathrm{Ca}\left(\mathrm{H}_{2} \mathrm{PO}_{4}\right)_{2} \cdot 2 \mathrm{H}_{2} \mathrm{O}$. Finally, the great advantage lies in the simplicity of the process of alkaline extraction and its easier implementation which makes it quite accessible to less equipped laboratories.

\section{REFERENCES}

[1] Childers, D. L., J. Corman, M. Edwards, J. J. Elser, "Sustainability challenges of phosphorus and food: solutions from closing the human phosphorus cycle", Bioscience., vol. 61, pp.117-124, 2011

[2] Dawson, C. J., J. Hilton, "Fertilizer availability in a resourcelimited world: production and recycling of nitrogen and phosphorus", Food Pol., vol. 36, pp. S14-S22, 2011.

[3] Gupta, D. K., S. Chatterjee, S. Datta, V. Veer, C. Walther, "Role of phosphate fertilizers in heavy metal uptake and detoxification of toxic metals". Chemosphere., Vol. 108, pp. 134 -144, 2014.

[4] Cordell, D., J. O. Drangert, S. White, The story of phosphorus: Global food security and for thought Global", Environ. Change., vol. 19, 292-305, pp. 2009.

[5] Pochitalkina, I. A., D. F. Kondakov, H. F. Le, and Ch. T. Wu, "Composition of Lean Apatite Ores from the Laokai Deposits", Russ. J. Inorg. Chem., vol. 63, pp. 1084-1086, 2018.

[6] Carpena, J., J. L. Lacout, «Des apatites naturelles aux apatites synthétiques: utilisation des apatites comme matrice de conditionnement de déchets nucléaires séparés », vol. 2, pp. 3-9, 1997.

[7] Benmoussa, H., M. Mikou, J. L. Lacout, "Synthesis and physicochemical study of new rare-earth containing vanadocalcic oxyapatites", Mater. Res. Bull., vol. 34, pp. 1429-1434, 1999.

[8] Ma, Q. Y., S.J. Traina, T.J. Logan, J. A. Ryan, "In situ lead immobilization by apatite", Environ. Sci. Technol., Vol. 27, pp. 1803-1810, 1993.

[9] Zhang, P., J. Miller, E. Wingate, L.L. Filho, "Beneficiation of phosphates", SME, Colorado, 2016.

[10] Daculsi, G., R. Z. LeGeros , M. Heughebaert, I Barbieux, "Formation of carbonate -apatite crystals after implantation of calcium phosphate ceramics", Calcif. Tissue. Int., vol. 46, pp. 20-27, 1990.

[11] Bouhaouss, A., A. Bensaoud, M. El Moussaouiti, M. Ferhat, «Analyse de l'apatite analogue aux biomatériaux par la spectroscopie infrarouge », Phys. Chem. News., vol. 1, pp. 125129,2001

[12] Raynaud, S., E. Champion, D. Bernache-Assolant, and P. Thomas, "Calcium phosphate apatites with variable $\mathrm{Ca} / \mathrm{P}$ atomic ratio. Part I. Synthesis, characterization, and thermal stability of powders", Biomaterials., vol. 23, pp. 1065-1072, 2002.

[13] Currey, J. D., "Bones: Structure and Mechanics", Princeton University Press, Princeton, 2002.
[14] El Ouardi, E., Mrani, M.I., Anoua, M., Chehouani, H., «Optimisation du traitement thermique d'un phosphate application au phosphate du bassin gantour au maroc », Mat. Tech., vol. 97, pp. 133-142, 2009

[15] Ibrahim, S. S., A. A. El-Midany, T. R. Boulos, "Effect of intensive mechanical stresses on phosphate chemistry as a way to increase its solubility for fertilizer application Physicochem", Probl. Miner. Process., vol. 44, pp 79-92, 2010.

[16] Reijntjes, C., B. Haverkort, A. Waters-Bayer, « une agriculture pour demain: introduction à une agriculture durable avec peu d'intrants externes », Karthala, Paris, 1995.

[17] Mellado, J., M. Llaurado, G. Rauret, "Determination of Pu, Am, $\mathrm{U}, \mathrm{Th}$ and $\mathrm{Sr}$ in marine sediment by extraction chromatography", Anal. Chim. Acta., vol. 443, pp. 81-90, 2001.

[18] Grynberg, J., E. Gouillart, M. H. Chopinet, J. T. Michael, Int. J. Appl. Glass. Sci. 6, 428 (2015)

[19] Fathia, M. H., A. Hanifia, V. Mortazavi, "Preparation and bioactivity evaluation of bone-like hydroxyapatite nanopowder", Journal of Materials Processing Tech., vol. 202, pp. 536-542, 2008.

[20] L. S. Pioro, L. S., A. M. Osnach, I. L. Pioro, "Production of Molten Defluorinated Phosphates in a Submerged Combustion Melter", Ind. Eng. Chem. Res., vol. 42, pp.6697-6704, 2003

[21] Smith, L. L., J. S. Crain, J. S. Yaeger, E.P. Horwitz, H. Diamond R. Chiarizia, "Improved separation method for determination actinides in soil samples", J. Radioanal. Nucl. Chem., vol. 194 pp. 151-156, 1995

[22] Galindo, C., L. Mougin, A. Nourreddine, "An improved radiochemical separation of uranium and thorium in environmental samples involving peroxide fusion", Appl. Radiat. Isot., vol.65, pp. 9-16, 2007.

[23] Maxwell, S. L., B. K. Culligan, J. B. Hutchison, R. B. Spencer, "Rapid fusion method for determination of actinides in feca samples", J. Radioanal. Nucl. Chem., vol. 298, pp. 1533-1542, 2013.

[24] Esnouf, C., «Caractérisation microstructurale des matériaux. Analyse par rayonnements $\mathrm{X}$ et électronique », P.P.U.R Lausanse, 2011.

[25] Faour, A., V. Prevot, C. Taviot - Gueho, "Microstructural study of different LDH morphologies obtained via different synthesis routes", J. Phys. Chem. Solids., vol. 71, pp. 487-490, 2010.

[26] Zhu, Q. X. , Y. M. Li, D. Han, "Co-substitution of carbonate and fluoride in hydroxyapatite: Effect on substitution type and content”, Front. Mater. Sci., vol.9, pp. 192-198, 2015.

[27] Kamalanathan, P., S. Ramesh, L. T. Bang, A. Niakan, C. Y. Tan J. Purbolaksono, H. Chandran, W. D. Teng, "Synthesis and sintering of hydroxyapatite derived from eggshells as a calcium precursor", Ceram. Int., vol. 40, pp. 16349-16359, 2014.

[28] Fleet, M. E., X. Liu, "Coupled substitution of type A and B carbonate in sodium bearing apatite", Biomaterials., vol.28, pp. $916-926,2007$ 
Appendix A: PDF File for the FAp

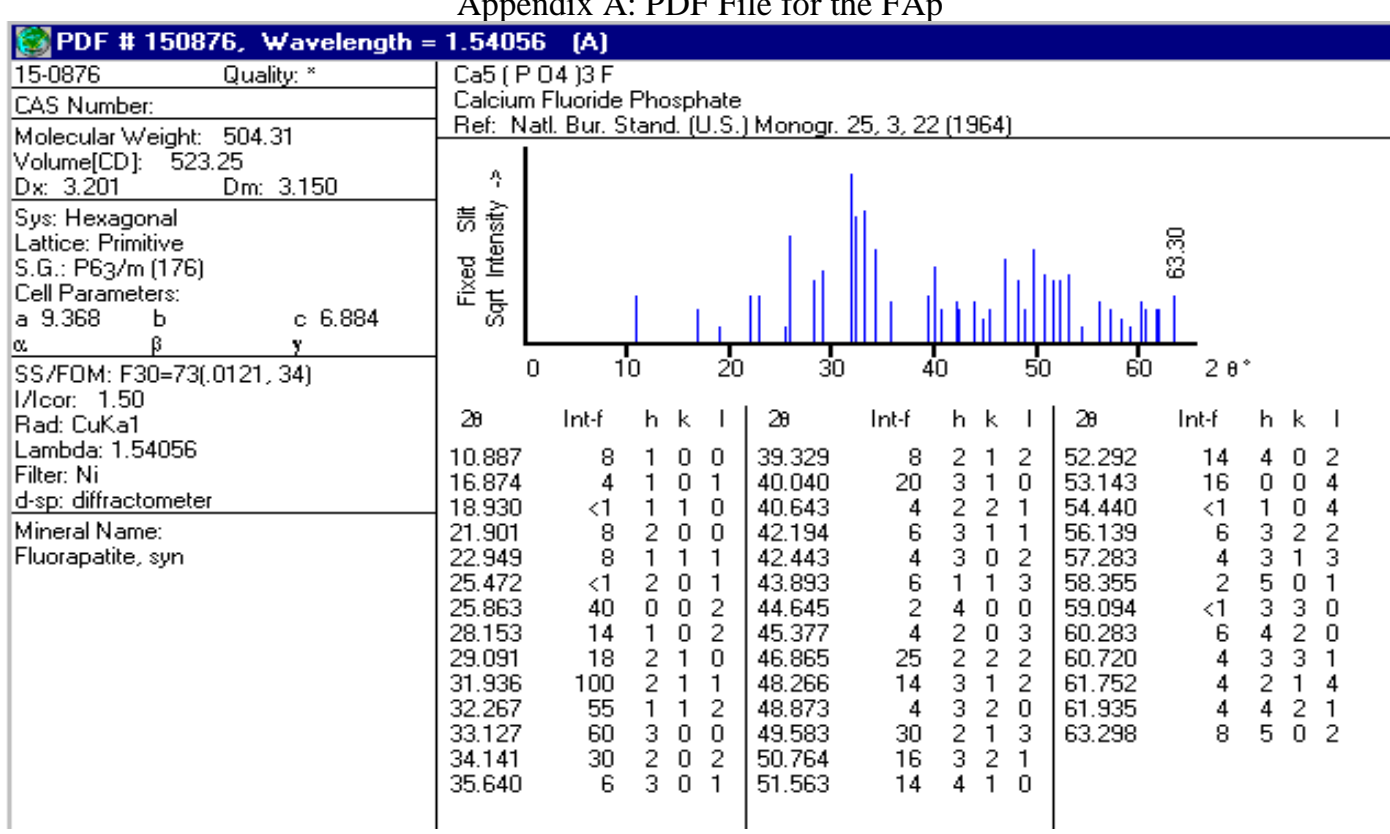

Appendix B: PDF File for the HAp

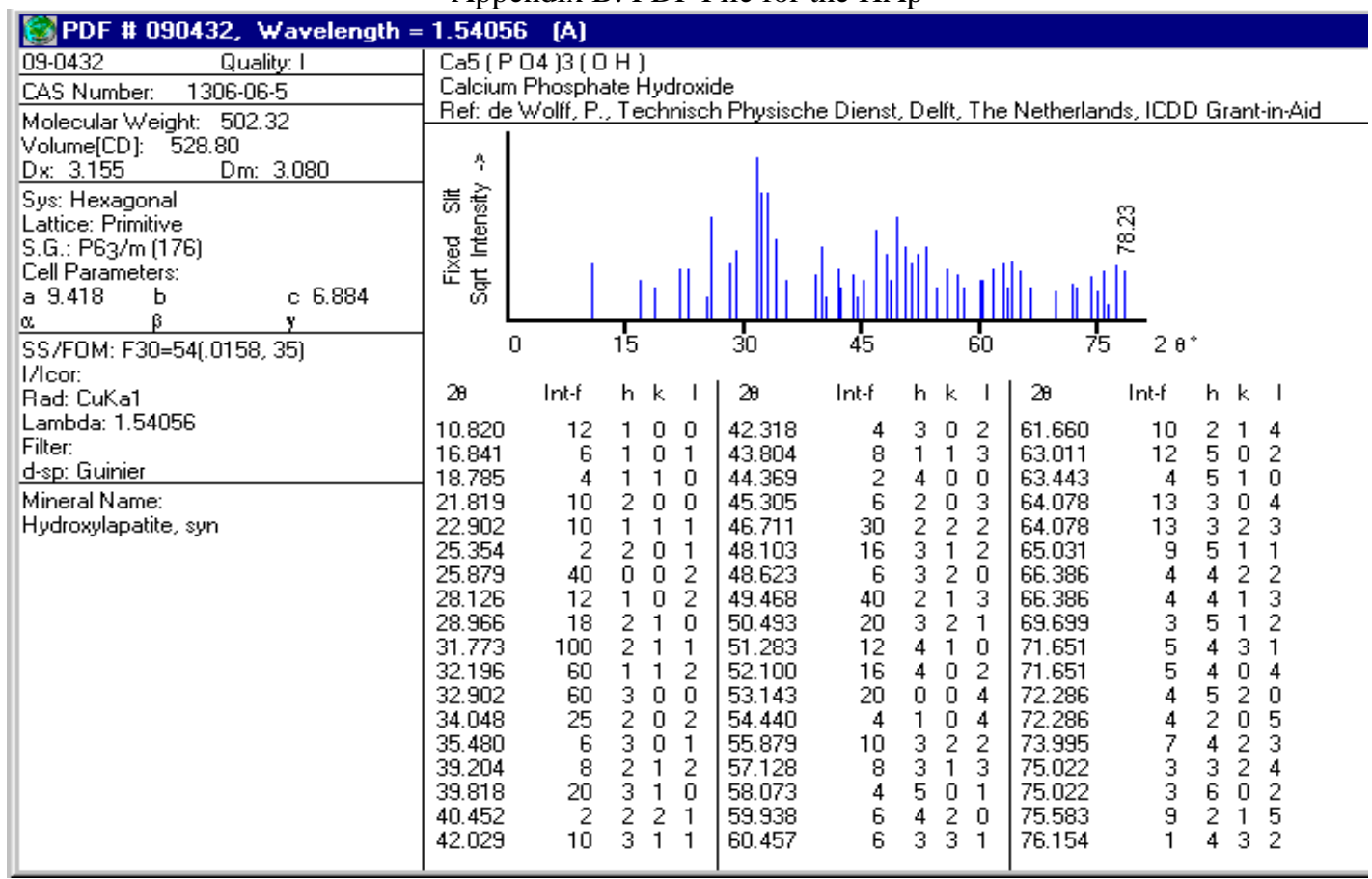

